\title{
Use of ICT in Securing Marketing Information among Small Scale Farmers in Niger State, Nigeria
}

\author{
Job N. Nmadu, Fatima. A. Aiyelitsoya, and Halima Sallawu
}

\begin{abstract}
This study examined the use of information communication technology (ICT) on securing marketing information among small scale farmers in Niger State, Nigeria. Data were obtained from 90 respondents through the use of structured questionnaire. The information collected was analyzed using descriptive statistics and multinomial logistic regression technique. Results of the analysis showed that majority of the respondents were in their active age of production and were married. Most of the respondents obtained their information from radio, television, and newspaper. The finding also indicated that the years spent in school and not the educational achievement is what is likely to increase the probability of awareness. Problems identified with regards to the usage of ICTs by the respondents include language barrier, poverty, and illiteracy. It was therefore recommended that government and nongovernmental organizations should collaborate to include ICT workshop and training in farmer education programmes, encourage programmes like NYSC ICT volunteer group, and translate technology to local languages.
\end{abstract}

Index Terms-Information communication technology, marketing, small scale farmers.

\section{INTRODUCTION}

Information and Communication Technology (ICT) is an umbrella term that includes any communication device or application encompassing; radio, television, cellular phones, computer, network of hardware and software, and satellite system. It covers all forms of computer and communication equipment and software used to create, design, store, transmit, interpret, manipulate, produce and present information in its various formats [1]. The interest in the application of ICT tools in agriculture arises from the perennial problems farmers face in accessing agricultural information [2]. Small scale farmers, who form majority of the farming population of Nigeria, tend to be poor in terms of access to agricultural production and marketing information services linking these farmers to markets therefore continues to be a major challenge. This challenge is as a result of poor connectivity, illiteracy, contents and costs [3]. Similarly, Information technology is becoming the main engine of economic growth. It will displace oil, just as oil displaced steel in the second half of the last century, as the main engine of the economic growth. Production will increasingly be knowledge based, and increasing advances in ICT, especially

Manuscript received January 28, 2013; revised March 13, 2013.

The authors are with the Dept. of Agricultural Economics and Extension Technology, Federal University of Tech., Minna, Nigeria (e-mail: job_nmadu@yahoo.co.uk, nightingale4ever@yahoo.co.uk, realhalma@yahoo.com) in the telecommunications sectors, will quicken the pace of globalization of trade [4].

ICT provide researchers with a steady avenue for the dissemination of research reports and findings [5]. Lack of Information and Communication Technology has led to low levels of agricultural commercialization among small scale farmers. This information-poverty traps farmers in subsistence farming thus preventing them from adopting profitable production and also keeps them supplying low paying market outlets [6]. In the absence of market information, opportunistic behavior (by traders and other market actors) tend to develop; such behavior encompasses cheating on the quality which in turn results in failure of traders to establish long-term business relations with farmers and other traders [7]. Information and Communication Technology has played a vital role in food production in Nigeria.

The assessment of the awareness and the use of ICTs is worthwhile not only because of its contribution to the economy of the nation, but in the final analysis, it will improve the lives of small scale farmers since information is an essential ingredient in agricultural development programme. Kenya Agricultural Commodity Exchange (KACE) is a private sector firm launched in 1997 to facilitate linkage between sellers and buyers of agricultural commodities, provide relevant and timely marketing information and intelligence, provide a transparent and competitive market price discovery mechanism and harness and apply information and communication technologies (ICTs) for rural value addition and empowerment. Studies in rural Thailand and Columbia also showed that the introduction of telephones enabled farmers to check prices regularly which led to a doubling of farm incomes while in Columbia, community telephone access increased trade, employment and government service delivery [8]. Djankov et al. [9] reported that independent radio broadcasting services have been found to be positively and significantly correlated with a range of development outcomes, including improved lives and better functioning markets. In Albania, studies show that information that is available to different markets has reduced price differences across markets [10]. Souter et al., [11] in his three country study (India, Tanzania and Mozambique) finds significant correlations between telecommunications and indicators of socio-economic development. In Niger, Aker [12] found that mobile phones reduced search costs by 50 percent compared with personal travel and that mobile phone use increased both traders' and consumers' welfare. Traders' profits increased by 29 percent not because they traded more products but because they obtained better prices through real-time market research 
conducted via mobile phone. Mobile phones were also associated with a 3.5 percent reduction in average consumer grain prices [13]. In Albania, studies showed that information that is available to different markets has reduced price differences across markets [10].

Some benefits of ICT include reduction in costs of agricultural information exchange and spurs commercialization thus improving the welfare of the farming communities. The availability of market information also enables farmers to check on the prices they receive vis-à-vis the prevailing market prices. In addition, an internet network among farmer organizations has dramatically increased farmers' incomes by providing information about crop status, weather, global market prices and training [14]. Timely access to market information via communication networks also helps farmers makes well informed decisions about what crops to plant and where to sell their produce and buy inputs. ICT provides opportunities for farmers to communicate with one another through email, mailing lists, and chat rooms. It also provides a quicker and easier access to more extensive and current agricultural information. ICT increase efficiency, provide access to new markets or services, create new opportunities for income generation. It is based on these advantages that this article seeks to examine the use of ICT in securing market information among small scale farmers in Niger State by seeking answers to the following research concerns: the socio-economic characteristics of the farmers in the study area, the various ICT media through which farmers obtain their information, the level of awareness of ICT by the respondents in the study area, the factors that affect the level of usage of information by the farmers and the constraints militating against the usage of ICT in the study area. To provide information on these research concern, this paper seeks to describe the socio-economic characteristics of the respondents; assess the level of awareness of ICT among small scale farmers; assess the various ICT media through which the farmers obtain their information; determine the factors that affect the level of awareness on ICT gadgets and their usage by the respondents; and identify the constraints militating against the usage of ICT in the study area. The findings in this study would provide a full understanding on the various ICT media through which the respondents obtain their market information, and what factors influences their level of awareness on these ICT media. The findings will provide a basis to policy authorities on the needed policy direction in order to integrate farming with ICT and thus promote greater commercialization of farmers by providing the necessary framework upon which their operational decisions are based.

\section{Methodology}

The study area was Niger State. The state's population is $3,950,249$ [15] and covers a total land area of $76,363 \mathrm{~km}^{2}$. It experiences distinct dry and wet seasons with annual rain fall varying from $1,100 \mathrm{~mm}$ in the northern part to $1,600 \mathrm{~mm}$ in the southern parts. The maximum temperature usually not more than $60^{\circ} \mathrm{C}$ is recorded between March and June, while the
Minimum is usually between December and January. The rainy seasons last for about 150 days in the Northern parts to about 120 days in the Southern parts of the State. The three principal ethnic groups of the state are the Nupe, the Gwari and the Hausa.

This study was based on primary data collected by administration of questionnaire. Simple random sampling technique was used to select Minna metropolis made of three Local Governments Areas (LGAs) namely Bosso, Chanchaga and Paikoro out of the four metropolises in Niger State i.e. Minna, Bida, Suleja and Kontagora. Minna metropolis has the added advantage of being more diverse in terms of the living population being the seat of the State Governor and is the only metropolis with more than one LGA. It also has both urban and rural areas and of higher living conditions than the other metropolises. Three villages were then selected randomly from each of the LGAs and 10 respondents were randomly selected in each of the villages, making a total of 90 respondents for the study. The data collected were socio-economic, awareness, frequency of use, importance and other information on ICT gadgets. Some of the information were collected using likert scale. The data was collected between January and July 2012.

The data collected were analyzed using descriptive statistical tool such as frequency tables, means, percentages, and standard deviations. These were employed to analyze socioeconomic characteristics, the level of awareness, importance and frequency of use of ICT gadgets, as well as constraints militating against the use of ICT in the study area. The factors affecting the level of awareness of the various ICT gadgets were determined using the multinomial logistic model. Multinomial models are appropriate when individuals can choose only one outcome from among the set of mutually exclusive, collectively exhaustive alternatives. The choice of this method is based on the fact that the level of awareness (dependent variable) is a categorical variable which can take three levels (low awareness $=0$, medium awareness $=1$, and high awareness=2). The probability that the $i$ th farmer belongs to the $j$ th risk behavior group reduces to:

$$
P_{i j}=\frac{e^{\beta_{j} X_{i}}}{1+\sum_{k=j}^{j} e^{\beta_{k} X_{i}}}
$$

The generalized multinomial model is expressed as

$$
P_{i j}=\frac{e^{\beta_{j} X_{i}}}{1+\sum_{k=0}^{j} e^{\beta_{k} X_{i}}}
$$

While the probability of being in the base outcome group is

$$
P_{i 0}=\frac{1}{1+\sum_{k=0}^{3} e^{\beta_{k} X_{i}}}
$$

To estimate the model the coefficients of the base outcome 
are normalized to zero $(0)$. This is because the probabilities for all the choices must sum up to unity. Hence, for 3 choices only (3-1) distinct sets of parameters can be identified and estimated. The natural logarithms of the odd ratio of equations (1) and (2) give the estimating equation as

$$
\ln \frac{P_{i j}}{P_{i 0}}=\beta_{i} X_{i}
$$

This denotes the relative probability of each of the other groups to the probability of the base outcome. The estimated coefficients for each choice therefore reflect the effects of $\mathrm{Xi}$ 's on the likelihood of the farmers choosing that alternative relative to the base outcome. The estimation was done using Stata Statistical/Data analysis 11.2 software [16]. The final estimates were selected based on the variables that converged during iteration. The coefficients of the base outcome were then recovered in line with in line with Nmadu et al. [17]

$$
\beta_{3}=-\left(\beta_{1}+\beta_{2}\right)
$$

where $\beta_{3}=$ coefficient of the variable of the base outcome (risk aversion), $\beta_{1}=$ estimated coefficient of the medium level awareness group, $\beta_{2}=$ estimated coefficient of the high level awareness group. In addition, the partial derivatives or marginal effects and quasi-elasticities of the model were obtained from the software. Finally, McFadden's [18] likelihood ratio index (LRI) also known as pseudo $\mathrm{R}^{2}$, similar to the $\mathrm{R}^{2}$ in a conventional regression, was computed as

$$
L R I=1-\frac{\ln L}{\ln L_{0}}
$$

where, $\ln \underline{L}=\log$-likelihood function

$\ln L_{0}=\log$-likelihood computed with only the constant term.

\section{RESULTS AND DisCUSSION}

The Socio-economic and demographic characteristics of the respondent of the respondents is presented on Table I showing that majority of the respondents are male and married with average of one wife and six children. The respondents are still in their productive years $(33 \pm 13$ years). Less than $50 \%$ of them have acquired secondary education, which is the highest attained haven spent about 6years acquiring formal education. Their farm holdings tend to be medium scale $(9.985 \pm 9.6 \mathrm{ha})$ scattered in more than three locations. The level of awareness of ICT gadgets and formats and the importance attached to ICT gadgets for securing market information are presented on Tables 2 and 3 showing that awareness is high for E-mail, Mobile phone, Radio, Television, Satellite receiver, Newspaper and I-pad while much importance is attached to Mobile phone, Internet, Radio and Television. Frequency of use of these ICT gadgets is presented on Table 4 showing that by the respondents frequently used Mobile phone, Internet, Radio, Television and Satellite receiver in seeking market information. Table V shows the number of ICT gadgets possessed by respondents, their mean purchase price and mean amount those who do not have are willing to spend to purchase one indicating that most respondents have only mobile phones, radio and television among all the ICT gadgets surveyed while quite a number expressed willingness to purchase what they do not have. The various market information sought for by the respondents is

\begin{tabular}{|c|c|c|}
\hline Variables & Frequency & Percentage \\
\hline \multicolumn{3}{|l|}{ Age } \\
\hline $11-20$ & 18 & 20.0 \\
\hline $21-30$ & 27 & 30.0 \\
\hline $31-40$ & 30 & 33.3 \\
\hline $41-50$ & 6 & 6.7 \\
\hline $51-60$ & 8 & 8.9 \\
\hline $61-70$ & 1 & 1.1 \\
\hline \multicolumn{3}{|l|}{ Gender } \\
\hline Male & 88 & 97.78 \\
\hline Female & 2 & 1.11 \\
\hline \multicolumn{3}{|l|}{ Marital Status } \\
\hline Single & 29 & 32.22 \\
\hline Married & 61 & 67.78 \\
\hline \multicolumn{3}{|c|}{ Number of wives } \\
\hline 0 & 29 & 32.22 \\
\hline 1 & 32 & 35.56 \\
\hline 2 & 22 & 24.44 \\
\hline 3 & 5 & 5.56 \\
\hline 4 & 2 & 2.22 \\
\hline \multicolumn{3}{|c|}{ Number of children } \\
\hline 0 & 29 & 32.22 \\
\hline $1-3$ & 15 & 16.67 \\
\hline $4-6$ & 23 & 25.56 \\
\hline $7-9$ & 10 & 11.1 \\
\hline $10-12$ & 7 & 7.78 \\
\hline $13-15$ & 2 & 2.22 \\
\hline $16-18$ & 2 & 2.22 \\
\hline $19-21$ & 1 & 1.11 \\
\hline $28-30$ & 1 & 1.11 \\
\hline \multicolumn{3}{|c|}{ Religious affiliations } \\
\hline Muslims & 88 & 97.78 \\
\hline Christians & 2 & 2.22 \\
\hline \multicolumn{3}{|c|}{ Educational level } \\
\hline None & 37 & 41.11 \\
\hline Primary & 19 & 21.11 \\
\hline Secondary & 30 & 33.33 \\
\hline Polytechnic & 2 & 1.11 \\
\hline $\begin{array}{l}\text { College of } \\
\text { education }\end{array}$ & 2 & 2.22 \\
\hline \multicolumn{3}{|c|}{ Years spent in formal education } \\
\hline 0 & 38 & 42.22 \\
\hline $1-3$ & 2 & 2.22 \\
\hline $4-6$ & 16 & 17.77 \\
\hline $7-9$ & 3 & 3.33 \\
\hline $10-12$ & 21 & 23.33 \\
\hline $13-15$ & 9 & 10 \\
\hline $16-18$ & 1 & 1.11 \\
\hline \multicolumn{3}{|l|}{ Farm Size } \\
\hline $1-2$ & 44 & 48.9 \\
\hline $2.1-3$ & 38 & 42.2 \\
\hline $3.1-4$ & 5 & 5.6 \\
\hline $4.1-5$ & 3 & 3.3 \\
\hline \multicolumn{3}{|c|}{ Number of plots of land } \\
\hline 0 & 15 & 16.67 \\
\hline 1 & 4 & 4.44 \\
\hline 2 & 4 & 4.44 \\
\hline 3 & 11 & 12.22 \\
\hline 4 & 32 & 35.56 \\
\hline 5 & 24 & 26.67 \\
\hline \multicolumn{3}{|l|}{ Income } \\
\hline Below 10,000 & 15 & 16.7 \\
\hline $10,001-20,000$ & 15 & 16.7 \\
\hline $20,001-30,000$ & 8 & 8.9 \\
\hline $30,001-40,000$ & 5 & 5.6 \\
\hline Above 40,000 & 47 & 52.2 \\
\hline
\end{tabular}
presented on Table 6 showing that only institutions involved in marketing is not sought by the respondents. 
TABLE II: DISTRIBUTION OF RESPONDENTS ACCORDING TO THE LEVEL OF AWARENESS OF ICT GADGETS AND FORMATS

\begin{tabular}{llll}
\multicolumn{4}{c}{ AWARENESS OF ICT GADGETS AND FORMATS } \\
\hline ICT Formats & Low & Medium & High \\
\hline E-mail & 64 & 7 & 19 \\
Internet & 75 & 10 & 5 \\
Mobile phone & 24 & 25 & 41 \\
Radio & 2 & 18 & 70 \\
Television & 6 & 20 & 64 \\
Satellite & 36 & 22 & 32 \\
Newspaper & 23 & 13 & 54 \\
Journal & 87 & 2 & 1 \\
I-pad & 53 & 16 & 21 \\
Blackberry & 79 & 8 & 3 \\
Online Paper & 89 & 0 & 1 \\
Podcast & 72 & 12 & 6 \\
\hline
\end{tabular}

TABLE III: DISTRIBUTION OF RESPONDENTS ACCORDING TO THE IMPORTANCE ATTACHED TO ICT GADGETS FOR SECURING MARKET

\begin{tabular}{|c|c|c|c|c|c|}
\hline & $\begin{array}{c}\text { Very } \\
\text { important }\end{array}$ & Important & $\begin{array}{l}\text { Not } \\
\text { sure }\end{array}$ & \multicolumn{2}{|c|}{$\begin{array}{l}\text { Not } \\
\text { important }\end{array}$} \\
\hline \multicolumn{6}{|l|}{ Mobile } \\
\hline phone & 45 & 10 & 6 & \multicolumn{2}{|c|}{2} \\
\hline Internet & 17 & 3 & 6 & \multicolumn{2}{|c|}{35} \\
\hline Email & 0 & 2 & 1 & \multicolumn{2}{|c|}{46} \\
\hline Radio & 33 & 21 & 6 & \multicolumn{2}{|c|}{15} \\
\hline Tele & 23 & 31 & 19 & \multicolumn{2}{|c|}{12} \\
\hline Satellite & 9 & 20 & 14 & \multicolumn{2}{|c|}{13} \\
\hline Newspaper & 1 & 9 & 12 & \multicolumn{2}{|c|}{15} \\
\hline Journal & 1 & 1 & 1 & \multicolumn{2}{|c|}{22} \\
\hline I-Pad & 1 & 0 & 0 & \multicolumn{2}{|c|}{21} \\
\hline Blackberry & 0 & 1 & 8 & \multicolumn{2}{|c|}{17} \\
\hline Online & & & & & \\
\hline newspaper & 0 & 0 & 0 & \multicolumn{2}{|c|}{22} \\
\hline $\begin{array}{l}\text { Pod cast } \\
\text { community }\end{array}$ & 0 & 1 & 0 & \multicolumn{2}{|c|}{23} \\
\hline radio & 0 & 2 & 4 & \multicolumn{2}{|c|}{16} \\
\hline Laptop & 0 & 0 & 1 & \multicolumn{2}{|c|}{22} \\
\hline Desktop & 0 & 0 & 0 & \multicolumn{2}{|c|}{22} \\
\hline \multicolumn{6}{|c|}{$\begin{array}{c}\text { TABLE IV: FREQUENCY OF USE OF THE VARIOUS ICT GADGETS BY } \\
\text { RESPONDENTS }\end{array}$} \\
\hline & Regularly & Occasionally & & & Never \\
\hline \multicolumn{6}{|l|}{ Mobile } \\
\hline Internet & 19 & 7 & & 9 & 54 \\
\hline Email & 0 & 1 & & 10 & 77 \\
\hline Radio & 33 & 26 & & 5 & 24 \\
\hline Television & 25 & 55 & & 6 & 4 \\
\hline Satellite & 10 & 29 & & 29 & 20 \\
\hline Newspaper & 1 & 15 & & 22 & 51 \\
\hline Journal & 0 & 4 & & 10 & 75 \\
\hline I-Pad & 0 & 0 & & 1 & 88 \\
\hline Blackberry & 1 & 0 & & 7 & 80 \\
\hline Online & & & & & \\
\hline information & 0 & 0 & & 0 & 88 \\
\hline $\begin{array}{l}\text { Pod cast } \\
\text { community }\end{array}$ & 0 & 0 & & 0 & 88 \\
\hline radio & 0 & 5 & & 6 & 77 \\
\hline Laptop & 3 & 2 & & 7 & 76 \\
\hline Desktop & 0 & 0 & & 6 & 82 \\
\hline Other & 3 & 4 & & 3 & 45 \\
\hline
\end{tabular}

Table VII gives the coefficient estimates of the variables included in the chosen multinomial logistic model of factors affecting the level of awareness of ICT in the study area. The final model shows that that the likelihood ratio $\left(\chi^{2}\right)$ is statistically significant at the $1 \%$ level meaning that the variables considered jointly exert a very significant influence on the level of awareness. This is an indication that all or some of the slope coefficients are significantly different from zero. It therefore means that the model is capable of showing and explaining the determinants of level of awareness of the respondents. This indication is also confirmed by the LRI of respondents, amount spent on purchase (+), farm size (+) and 0.5533 which is quite higher than that obtained by Nmadu et al. [17], Rahji and Fakayode [19], Abadi ghadim and Pannell, [20] and Zepeda [21]. The model further shows that while number of years spent in formal education (+) and educational age (-) also determined the probability of high level of awareness significantly. Finally, Table VIII shows the constraints encountered in using ICT and their severity showing that poverty and language barrier are the most severe setback to the use of ICT by the respondents.

TABLE V: Number of ICT GADGETS POSSESSED By RESPONDENTS, THEIR Mean Purchase Price And Mean Amount Those Who Do Not Have ARE WILLING TO SPEND TO PURCHASE ONE

\begin{tabular}{|c|c|c|c|c|c|c|}
\hline & & 1 & 2 & 3 & 4 & 5 \\
\hline $\begin{array}{l}\text { t very } \\
\text { portant }\end{array}$ & Mobile phones & 113 & 24 & 0 & 6435.56 & 2007.78 \\
\hline & internet & 0 & 0 & 0 & 0 & 0 \\
\hline $\begin{array}{l}24 \\
29\end{array}$ & Email & 0 & 0 & 0 & 105.56 & 377.78 \\
\hline 40 & Radio & 77 & 18 & 0 & 5025.56 & 3930 \\
\hline $\begin{array}{c}13 \\
4\end{array}$ & Television & 51 & 10 & 0 & 5486.67 & 8033.33 \\
\hline 34 & Satellite dish & & & & & 17916.6 \\
\hline 53 & receiver & 4 & 0 & 0 & 1722.22 & 7 \\
\hline $\begin{array}{l}65 \\
66\end{array}$ & Newspapers & 3 & 0 & 0 & 7.78 & 97.44 \\
\hline 62 & Journals & 0 & 0 & 0 & 0 & 333.33 \\
\hline 66 & I pad & 0 & 0 & 0 & 0 & 0 \\
\hline 65 & Blackberry & 0 & 0 & 0 & 0 & 8814.61 \\
\hline 67 & newspaper & 0 & 0 & 0 & 0 & 0 \\
\hline $\begin{array}{l}67 \\
67\end{array}$ & Podcast & 0 & 0 & 0 & 0 & 0 \\
\hline & $\begin{array}{l}\text { Community } \\
\text { radio }\end{array}$ & 0 & 0 & 0 & 0 & $\begin{array}{c}0 \\
22449.4\end{array}$ \\
\hline & Laptop & 0 & 0 & 0 & 555.56 & $\begin{array}{c}4 \\
28644.4\end{array}$ \\
\hline & Desktop PC & 0 & 0 & 0 & 0 & 4 \\
\hline & Others & 8 & 0 & 0 & 450 & 1705.56 \\
\hline
\end{tabular}

TABLE VI: DISTRIBUTION OF RESPONDENTS ACCORDING TO THE MARKET INFORMATION SOUGHT FOR

\begin{tabular}{lrrrr}
\hline $\begin{array}{l}\text { Types of market } \\
\text { information } \\
\text { sought }\end{array}$ & Regularly & Sometimes & Rarely & Never \\
\hline $\begin{array}{l}\text { Price of the } \\
\text { products }\end{array}$ & 50 & 31 & 6 & 3 \\
$\begin{array}{l}\text { Price changes } \\
\text { Grading of }\end{array}$ & 49 & 30 & 6 & 5 \\
products & 22 & 13 & 3 & 52 \\
Institutions & 1 & 1 & 0 & 88 \\
$\begin{array}{l}\text { Available } \\
\text { markets }\end{array}$ & 31 & 19 & 4 & 36 \\
Consumers & 23 & 14 & 3 & 51 \\
$\begin{array}{l}\text { Sales } \\
\text { information }\end{array}$ & 28 & 17 & 3 & 42 \\
Product planning & 8 & 5 & 1 & 77 \\
Weather report & 8 & 5 & 1 & 76 \\
\hline
\end{tabular}

The result on Table I shows that most of the farmers were still within the economically productive and technological age. This agrees with Meera et al. [22] and Ndag et al. [23] in their studies have concluded that younger farmers prefer to 
use ICT more compared to older farmers. One factor responsible for this is that the younger farmers have higher educational achievement and hence exposed more to ICT gadgets and formats. The level of education of farmers is assumed to influence the level of awareness and ability to adopt innovation. Whether this assertion is the case in this study is to be confirmed shortly. In addition, there is an indication that the farmers' income level is high, as of them possessed more than one ICT format (Mobile phone, Radio). This agrees with the research carried out by Cecchini and Scott [24] which revealed that Farmers with high incomes had more than one ICT (normally radio and mobile phone) and therefore were in a better position to access market information through these items than those with less income who had only one type of ICT.

TABLE VII: MULTINOMIAL LOGISTIC REGRESSION ESTIMATES OF FACTORS AFFECTING THE LEVEL OF AWARENESS OF ICT IN THE STUDY AREA

\begin{tabular}{|c|c|c|c|}
\hline & $\begin{array}{l}\text { Low (base } \\
\text { outcome) }\end{array}$ & Medium & High \\
\hline Religion & 31.58532 & $\begin{array}{l}-2.851622 \\
(5044.439)\end{array}$ & $\begin{array}{l}-28.7337 \\
(1415.406)\end{array}$ \\
\hline $\begin{array}{l}\text { Amount spent on } \\
\text { purchase }\end{array}$ & -0.00127 & $\begin{array}{l}.0002867 \\
(.0002819)\end{array}$ & $\begin{array}{l}.0009858 * * \\
(.0004148)\end{array}$ \\
\hline $\begin{array}{l}\text { Number of years } \\
\text { already use ICT }\end{array}$ & 0.279191 & $\begin{array}{l}-.0242216 \\
(.125407)\end{array}$ & $\begin{array}{l}-.2549689 \\
(.22577)\end{array}$ \\
\hline $\begin{array}{l}\text { Income from non-farm } \\
\text { sources }\end{array}$ & $-6.1 \mathrm{E}-07$ & $\begin{array}{l}3.09 \mathrm{e}-07 \\
(1.34 \mathrm{e}-06)\end{array}$ & $\begin{array}{l}2.98 \mathrm{e}-07 \\
(1.75 \mathrm{e}-06)\end{array}$ \\
\hline Total farm income & $2.65 \mathrm{E}-06$ & $\begin{array}{l}-9.57 e-07 \\
(1.57 e-06)\end{array}$ & $\begin{array}{l}-1.69 \mathrm{e}-06 \\
(1.49 \mathrm{e}-06)\end{array}$ \\
\hline Farm size & -0.1675 & $\begin{array}{l}-.0475948 \\
(.1444892)\end{array}$ & $\begin{array}{l}.2150959^{*} \\
(.1345725)\end{array}$ \\
\hline No of plots & -0.63837 & $\begin{array}{l}.3954043 \\
(.3671769)\end{array}$ & $\begin{array}{l}.2429625 \\
(.3919486)\end{array}$ \\
\hline No of children & -0.35487 & $\begin{array}{l}-.0174802 \\
(.3536431)\end{array}$ & $\begin{array}{l}.372351 \\
(.4143786)\end{array}$ \\
\hline $\begin{array}{l}\text { Number of years spent } \\
\text { in formal education }\end{array}$ & -2.46255 & $\begin{array}{l}.7886686^{* *} \\
(.3253022)\end{array}$ & $\begin{array}{l}1.673886^{* * * *} \\
(.6178728)\end{array}$ \\
\hline $\begin{array}{l}\text { Educational level } \\
\text { (secondary) }\end{array}$ & 18.89874 & $\begin{array}{l}-7.321308 * * \\
(3.171993)\end{array}$ & $\begin{array}{l}-11.57743 * * \\
(5.072752)\end{array}$ \\
\hline Marital status & 0.584862 & $\begin{array}{l}-.0980686 \\
(1.564173)\end{array}$ & $\begin{array}{l}-.4867929 \\
(1.87616)\end{array}$ \\
\hline Age & 0.608503 & $\begin{array}{l}-.1294683 \\
(.1478901)\end{array}$ & $\begin{array}{l}-.4790346^{*} \\
(.2720705)\end{array}$ \\
\hline Constant & -28.9372 & $\begin{array}{l}1.052042 \\
(5044.441)\end{array}$ & $\begin{array}{l}27.88516 \\
(1415.42)\end{array}$ \\
\hline
\end{tabular}

$\mathrm{LR} \mathrm{chi}^{2}=66.28 * * *$ Log likelihood $=-26.753232$ Pseudo $\mathrm{R}^{2}=0.5533$ $\mathrm{NB}$ : Values in parenthesis are standard errors, $* * * \mathrm{P}<0.01, * * \mathrm{P}<0.05$, $* \mathrm{P}<0.10$

TABLE VIII: DISTRIBUTION OF RESPONDENTS ACCORDING TO SEVERITY OF CONSTRAINTS ENCOUNTERED WHEN USING ICT

\begin{tabular}{|c|c|c|c|}
\hline Constraints & Serious & Mild & $\begin{array}{c}\text { Not a } \\
\text { constraint }\end{array}$ \\
\hline Illiteracy (lack of education) & 46 & 36 & 8 \\
\hline Poor network coverage & 5 & 25 & 60 \\
\hline $\begin{array}{l}\text { Poor access to ICT } \\
\text { infrastructure }\end{array}$ & 7 & 45 & 38 \\
\hline Poverty & 52 & 36 & 2 \\
\hline Lack of technical know-how & 18 & 53 & 19 \\
\hline $\begin{array}{l}\text { Poor access to internet } \\
\text { connectivity }\end{array}$ & 7 & 36 & 47 \\
\hline $\begin{array}{l}\text { Inadequate capacity and } \\
\text { affordability }\end{array}$ & 12 & 50 & 28 \\
\hline Language barriers & 58 & 25 & 7 \\
\hline
\end{tabular}

The results on Tables III-IV indicated that level of awareness, importance of the ICT gadgets in securing market information, frequency of use of the ICT gadgets and formats, and the type and number of gadgets possessed are not uniform. The result further shows that the respondents used radio, television, newspaper and mobile phones more to obtain their marketing information. The least ICT gadgets used were podcast, online papers and blackberry. This implies that even though the respondents own these gadgets, they do not use them to obtain marketing information. According to Djankov et al. [9], independent radio broadcasting services have been found to be positively and significantly correlated with a range of development outcomes, including improved lives and better functioning markets.

The results on Table VI showed that prices and price change information are most sought after by the respondents. This probable was to enable them set prices that would satisfy them and the consumers. The least sought after is information on marketing institutions, product planning and weather. Probably this information is not needed because there is no specialization in Nigerian agriculture. Farmers tend to produce based on previous years' experience thereby being caught in the so-called cobweb problem. In addition, various grades of agricultural produce is not a key information because most agricultural produce in Nigeria are not sold by grades neither is there any standard unit of measure.

The results on Table VII is quite contradictory with regards to number of years spent in formal education $(+)$ and educational level (secondary) (-) and contrary to the views expressed earlier. The implication of this finding is that the years spent in school and not the educational achievement is what is likely to increase the probability of awareness. The average number of years spent in school is about 6 years which suggest that most of the respondents might have just attempted secondary school but did not complete. Of course, it is important to stress to the farmers that education is key to achieving a sustained increase in farm output through easy and cheap information exchange, the platform which is provided by ICT. Even the planned distribution of mobile phones to $5 \mathrm{~m}$ small scale farmers in Nigeria during the 2013 fiscal year can only achieve the stated objectives if the issue of education and training is intensified to let the farmers know the benefit derivable by the exercise. Surprisingly, age of the farmer tends to reduce the probability of awareness of ICT platform. As the farmer grow older, so also are the responsibilities growing, like paying children school fess or cost of health care; providing food for his growing family etc. In fact in this community, the size of the family seems to be large. This might deprive the farmer for seeking anything outside the basic necessities of life including ICT. Purchase power and farm size tends to increase the probability of awareness which is in line with expectation. As the farmer open more farmlands, there is increase income which increases his purchasing power.

The results on Table VIII shows that most of the respondents had language barrier as the most serious constraint as indicated by Deraman and Samsul [25]. They asserted that language is one of the main problems faced by the agriculture community in using ICT. The result also showed that Poverty was one of the major problems faced by small scale farmers; this deprives the farmers from expanding their farms and making use of ICT as a result, information 
poverty sets in. This information poverty traps farmers into subsistence farming thus preventing them from adopting profitable production [6].

\section{CONCLUSION AND RECOMMENDATIONS}

This study was designed to examine the use of ICT in securing marketing information among small scale farmers in Niger state. Descriptive analytical tool and multinomial logistic regression analysis were used to analyze the data. The result of the descriptive analysis showed that $63.3 \%$ of the respondents were between the ages of 21-40years. It was noticed that large proportion of the respondents were married $(67.8 \%)$, with fairly large household size, and $41.1 \%$ of the respondents were not educated. The result also shows that majority of the respondents were more aware of Radio, Television and Newspapers as a source of market information but they obtained their information through Radio, Television and Newspapers respectively. The type of information they mainly sought for were those of prices and price changes respectively. Further analysis of the result shows that language barrier, poverty, and illiteracy were the most serious problem encountered by the respondents. The finding also show the number of years in formal education increased the probability of awareness while the attaining the level of secondary education tend to reduce awareness. Based on this, efforts should be made by the government to ensure that ICT workshops and trainings are included in farmer education, entrepreneur development and skills acquisition programmes in agriculture, which will assist in market orientation and appropriate technology acquisition. In addition, there is need to translate the technologies to local languages especially radio broadcasts. The government should encourage programmes like National Youth Service Corps (NYSC) ICT Volunteer Group to provide sensitization at the rural communities where they are posted. The NYSC can be an effective tool for fostering ICT development in rural communities as it can provide the man-power and high level competence required to manage ICT centre and train locals on ICT use for agricultural development purposes. Besides, due to its wide coverage of rural areas, networking between NYSC groups in various communities can foster rural-urban communication, extending information to rural farmers and providing relevant market access information.

\section{REFERENCES}

[1] E. C. Madu, "Computerized Reference Source and Traditional Printed Reference Source: A Comparison of the Old and the New in Library Services," Information Science and Technology for Library Schools in Africa, Madu, E.C. et al. (ed) Ibadan: Evi-Coleman Publications, 2003.

[2] J. J. Okello, R. M. Okello, and E. Adera-Ofwona, "Awareness and use of mobile phones by smallholder farmers in Kenya," in Blessing Maumbe (Ed), E-Agriculture and E-Government for Global Policy Development: Implications and Future Directions, 2009.

[3] CTA. ICTs: Transforming Agricultural Extension? An e-discussion, 20th August - 29th September, 2003.

[4] B. J. Danial, "The Nigerian Economy in the 21st century: Prospects and Challenges Ahead," An article on the Information technology revolution of the new century, vol. 39, no. 68, pp. 46-58, 2006.

[5] M. O. Yusuf, "Information and Communication Technology and Education," Analyzing the Nigerian National Policy for Information Technology, 2006.
[6] N. Ashraf, X. Gine, and D. Karlan, Finding missing markets (and a disturbing epilogue): Evidence from an export crop adoption and marketing intervention in Kenya, 2007.

[7] M. Fafchamps and E. Gabre -Madhin, "Agricultural markets in Benin and Malawi," African Journal of Agricultural and Resource Economics, vol. 1, no. 1, pp. 67-94, 2006.

[8] ITU, $2^{\text {nd }}$ World telecommunication indicators meeting, Final report, Geneva, 1999.

[9] S. Djankov, C. McLeish, T. Nenova, and A. Sheifer, "Who owns the media?" Journal of Law and Economics, vol. 46, no. 2, 2001.

[10] A. W. Shepherd, "Marketing and rural finance farm radio as a medium for market information dissemination," First International Workshop on Farm Radio Broadcasting, 2000.

[11] D. Souter, N. Scott, C. Garforth, R. Jain, O. Mascarenhas, and K. McKemey, "The economic impact of telecommunications on rural livelihoods and poverty reduction: A study of rural communities in India (Gujarat), Mozambique, and Tanzania," Report of DFID KaR Project 8347, 2005.

[12] J. C. Aker, "Does digital divide or provide?" The impact of cell phones on grain markets in Niger Job Market Paper, University of California, Berkeley, 2008.

[13] E. Alampay, "Analysing Socio Demographic Differences in the Access and Use of ICT in the Philippines Using the Capability Research," Journal of Information System in Developing Countries, 2006, pp. 1-39.

[14] UNDP (United Nations Development Programme), Making new technologies work for human development, United Nations Development Programme, 2001.

[15] NPC (National Population Commission), The 2006 Population and housing Census of Nigeria, Abuja, 2006.

[16] Stata. Stata ${ }^{\circledR}$ Statistics/Data Analysis 11.2. StataCorp 4905 Lakeway Drive College Station, Texas 77845 USA, 2009.

[17] J. N. Nmadu, G. P. Eze, and A. J. Jirgi, "Determinants of risk status of small scale farmers in Niger State, Nigeria," British Journal of Economics, Management \& Trade, vol. 2, no. 2, pp. 92-108, 2012.

[18] D. McFadden, "The Measurement of Urban Travel Demand," Journal of Public Economics, vol. 3, pp. 303-328, 1974.

[19] M. A. Y. Rahji and S. B. Fakayode, "A Multinomial Logit Analysis of Agricultural Credit Rationing by Commercial Banks in Nigeria," International Research Journal of Finance and Economics, Issue 24, 2009, pp. 90-100.

[20] A. K. A. Ghadim and D. J. Pannell, "A conceptual framework of adoption of an agricultural innovation," Agricultural Economics, vol. 21, pp. 145-154, 1999.

[21] L. Zepeda, "Adoption of Capital Versus Management Intensive Technologies," Canadian Journal of Agricultural Economics, vol. 38, pp. 457-469, 1990

[22] S. N. Meera, A. Jhamtani, and D. M. U. Rao, "Information and Communication Technology in Agricultural Development," A comparative Analysis of three Project from India. Agricultural Research and Extension Network (AGREN) Network Paper, no. 135, 2004, pp. 14.

[23] I. Ndag, R. A. Sanusi, and E. O. Aigbekaen, "Comparative Analysis of Information and Communication Technology (ICT) Use by Agricultural Extension Workers in South-West and North-Central Nigeria," presented at 19th Annual International Information Management Association, San Diego, California, United States of America, 13-15 October, 2008.

[24] S. Cecchini and C. Scott, "Can information and communication technology applications contribute to poverty reduction?" Lessons from rural India, information technology for development, 2003, vol. 10, no. 2, pp. 73-84.

[25] A. B. Deraman and A. K. S. Bahar, "Bringing the Farming Community into Internet Age: A Case Study," Journal of Informing Science, vol. 4 , 2000, pp. 207-214.

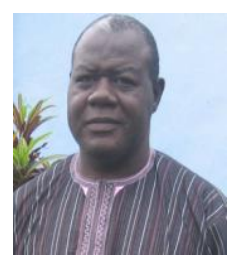

Job N. Nmadu was born in Niger State, Nigeria, became a Member of Agricultural Society of Nigeria (ASN) in 1992, Nigerian Association of Agricultural Economists (NAAE) in 2001, Asia-Pacific Chemical, Biological \& Environmental Engineering Society (APCBEES) in 2012 and International Economics Development Research Center (IEDRC) in 2013. He started his career development at St. John's Primary School, Bida in 1972. He obtained GCE in 1982 at GSS Suleja and proceeded to Ahmadu Bello University where he obtained BSc (Agriculture) in 1987, MSc (Agricultural Economics) in 1998 and $\mathrm{PhD}$ 
(Agricultural Economics specializing in econometric modeling of sorghum economy) in 2002.

Dr. Nmadu has served in a number of Committees within and outside the academic community including Environmental Impact Assessment Panel Review for Federal Ministry of Environment, Abuja, Honourary Degrees Committee for Federal University of Technology and Human Capacity Syndicate Research Group for University Board of Research, Federal University of Technology among others. He also served as consultant for Environmental Impact Assessment for Etisalat.

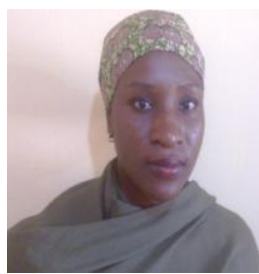

Fatima A. Aliyu was born in Kaduna State on the $29^{\text {th }}$ of October, 1986. She is a graduate of the Federal University of Technology, Minna, Nigeria (2012); where she obtained a B. Tech. degree in General Agriculture with option in Agricultural Economics and Extension Technology with a First class. She obtained her secondary education in Iyekhei Girls' College, Auchi, Edo State.

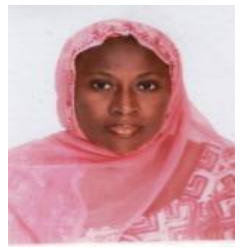

Halima Sallawu was born in Agaie Local Government of Niger State on 19th November 1981. Attended Suleiman Primary School Agaie from 1986 to 1992, Maryam Babangida Girls' Science College Minna from 1994 to 1999, Federal College of Education Kontagora from 2001 to 2004 and obtained NCE in Agricultural Education (double major). Shen then proceeded to, Federal University of Technology Minna between 2005 and 2011 where she obtained B. Tech. degree in General Agriculture with option in Agricultural Economics and Extension Technology.

She worked with Niger State Ministry of Science And Technology as Agricultural Officer from 2003 to 2010. She is currently Graduate Assistan Federal University of Technology Minna, Nigeria.

Mrs. Halima is a Member of Nigerian Association of Agricultural Economist. 